\title{
Poland syndrome: a case report
}

\author{
Apurva Bansal, ${ }^{1}$ Keerthi Reddy, ${ }^{2}$ Kristen Dinsmore, ${ }^{3}$ Alexei Gonzalez-Estrada ${ }^{4}$
}

'Department of Internal

Medicine, East Tennessee State University James H Quillen College of Medicine, Johnson City, Tennessee, USA ${ }^{2}$ Pediatrics, East Tennessee State University, Johnson City,

${ }^{3}$ Department of Biological Sciences, East Tennessee State University, Johnson City, Tennessee, USA

${ }^{4}$ Department of Pediatrics, East Tennessee State University James H Quillen College of Medicine, Johnson City, Tennessee, USA

\section{Correspondence to} Dr Alexei Gonzalez-Estrada, gonzalez.alexei@gmail.com

Accepted 14 July 2017 Tennessee, USA

\section{DESCRIPTION}

Poland syndrome (PS) is a rare chest wall developmental anomaly characterised by ipsilateral agenesis/hypoplasia of the sternocostal head of pectoralis major, hypoplasia of nipple or breast, absence of subcutaneous fat, multiple rib abnormalities, elevated and rotated scapula (Sprengel deformity) and ipsilateral digit abnormalities (brachydactyly, syndactyly). These findings vary and all are rarely found in a single individual.

Our case involves an 8-year-old boy with no medical history who presented for evaluation of chronic rhinitis. There was no breathing or cardiac complaints on review of systems. Physical examination showed chest asymmetry with right anterior chest wall depression and flattening of the right pectoral region with displaced nipple (figure 1). Abduction of the shoulders showed absence of the sternocostal head of pectoralis major. Hand examination did not show any signs of ipsilateral digital abnormality.

PS was first described by Alfred Poland in 1840 . Aetiology of PS remains unknown. It is rarely genetically inherited and is regarded as a sporadic event. It has been suggested that during the sixth week of gestation, the injury occurs due to regional vascular defect of the subclavian artery. ${ }^{1}$ It is a period associated with splitting of the two heads of pectoralis major and the development of tissues between the digits.

Treatment is primarily reconstructive surgery depending on the severity of the malformation, gender and patient preference. Generally, the reconstructive path is complex and must be performed stepwise because the malformation

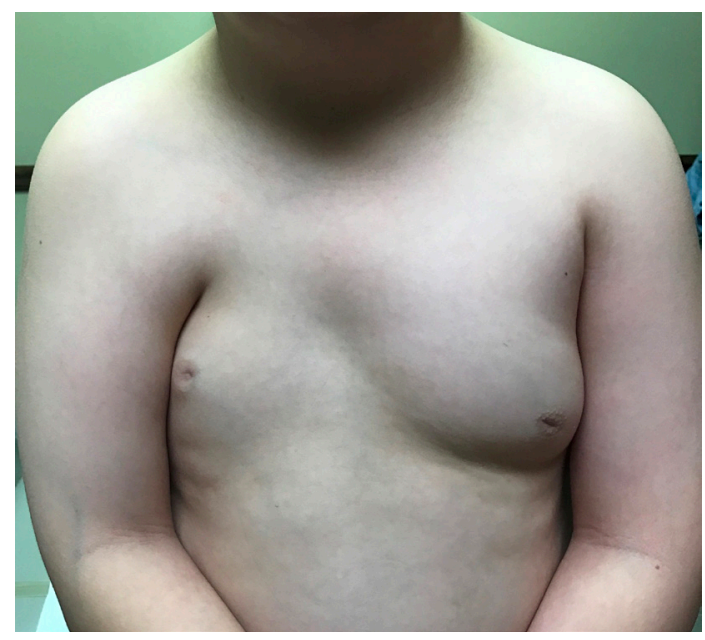

To cite: Bansal A, Reddy K, Dinsmore K, et al. BMJ Case Rep Published Online First: [please include Day Month Year]. doi:10.1136/bcr-2017 221564

\section{CrossMark}

Figure 1 Chest asymmetry with right anterior chest wall depression and flattening of the right pectoral region with displaced nipple.

\section{Patient's perspective}

My son was first diagnosed with Poland syndrome as an infant. Naturally, being his mother, I searched in medical journals and books and anything published on the computer. I must say that I was truly disappointed. There isn't a lot of information about and I'm assuming it's because research was limited. I would also like to point out that I could not find one photograph of what Poland syndrome looked like. Your interest in this will help so many that don't know what I know, and it's very limited. Good Luck to you, Dr Gonzalez. Please remember to send me a copy of your article.

\section{Learning points}

- Poland syndrome is a developmental disorder characterised by hypoplasia of the sternocostal head of pectoralis major, ipsilateral digit abnormalities (such as brachydactyly, syndactyly), nipple/breast and other chest wall and scapula abnormalities.

- Aetiology is unclear but is thought to be secondary to vascular defect of the subclavian artery during the sixth week of gestation.

- Surgical planning for patients with Poland syndrome is characterised by a personalised approach, which must consider patient's physical and mental aspects.

involves alteration of different tissues (skin, subcutaneous tissue, muscle, breast). Cardiac or respiratory complaints should alert the healthcare provider for further work-up. Left-sided PS has been associated with dextrocardia particularly in patients with agenesis of two or more ribs. ${ }^{2}$ The "vascular theory' has been proposed for other variants of this syndrome such as Mobius and Klippel-Fiel. ${ }^{1}$ Several cases have described an association with neoplasms such as neuroblastoma, leukaemia, leiomyosarcoma, breast cancer and Wilms tumour. ${ }^{3}$

Reconstructive surgery is planned for this patient after growth completion. The patient has remained asymptomatic and will follow up with cardiothoracic surgery after growth completion.

Contributors $A B$ contributed to the conception and design of the study, data generation, analysis and interpretation of the data, preparation and critical revision of the manuscript. KR contributed to the conception and design of the study, analysis and interpretation of the data, preparation and critical revision of the manuscript. KD contributed to the conception and design of the study, analysis and interpretation of the data, preparation and critical revision of the manuscript. AG-E contributed to 


\section{Images in...}

the conception and design of the study, analysis and interpretation of the data, preparation and critical revision of the manuscript.

Competing interests None declared.

Patient consent Obtained from guardian.

Provenance and peer review Not commissioned; externally peer reviewed.

(c) BMJ Publishing Group Ltd (unless otherwise stated in the text of the article) 2017. All rights reserved. No commercial use is permitted unless otherwise expressly granted.

\section{REFERENCES}

1 Bavinck JN, Weaver DD. Subclavian artery supply disruption sequence: hypothesis of a vascular etiology for Poland, Klippel-Feil, and Möbius anomalies. Am J Med Genet 1986;23:903-18.

2 Lacorte D, Marsella M, Guerrini P. A case of Poland syndrome associated with dextroposition. Ital J Pediatr 2010;36:21.

$3 \mathrm{Ji} \mathrm{J}$, Zhang S, Shao C, et al. Poland's syndrome complicated with breast cancer: mammographic, ultrasonographic, and computed tomographic findings. Acta Radiol 2008;49:387-90.

Copyright 2017 BMJ Publishing Group. All rights reserved. For permission to reuse any of this content visit http://group.bmj.com/group/rights-licensing/permissions.

BMJ Case Report Fellows may re-use this article for personal use and teaching without any further permission.

Become a Fellow of BMJ Case Reports today and you can:

- Submit as many cases as you like

- Enjoy fast sympathetic peer review and rapid publication of accepted articles

- Access all the published articles

Re-use any of the published material for personal use and teaching without further permission

For information on Institutional Fellowships contact consortiasales@bmjgroup.com

Visit casereports.bmj.com for more articles like this and to become a Fellow 